\title{
The Effect Of Competence and Independence to Work Effectiveness Of Auditor
}

\author{
Ismet Sulila \\ Program Studi Ilmu Administrasi Publik, Universitas Negeri Gorontalo \\ Indonesia 96128 \\ E-mail: ismet.sulila@gmail.com
}

Received: 25 November 2020; Revised: 12 Desember 2020; Accepted: 30 Desember 2020

\begin{abstract}
The research objective was to find out the influence of competence and independence on the work effectiveness of auditor at Regional Inspectorate of Gorontalo Province either partially or simultaneously. The approach used in this research was quantitative. The research method used expost facto. The technique of data analysis used multiple regression. The research finding showed that (1) competence of auditor had a positive and significant influence on the work effectiveness of auditor at Regional Inspectorate of Gorontalo Province by the determinant value of 23,50\%. The meaning of the positive coefficient indicated that the higher the competence of auditor, the more effective work result of auditor at Regional Inspectorate of Gorontalo Province. (2) Independence of auditor had a positive and significant influence on the work effectiveness of auditor at Regional Inspectorate of Gorontalo Province by determinant value of 56,60\%. The meaning of positive coefficient indicated that the more independent of auditor in doing inspection and functional supervision function, the more optimum work effectiveness of auditor at Regional Inspectorate of Gorontalo Province. (3) The competence and independence of auditor, simultaneously, had a significant influence on the work effectiveness of auditor at Regional Inspectorate of Gorontalo Province by determinant value of $61,70 \%$.
\end{abstract}

Keywords: Effectiveness; Auditor Competence; Auditor Independence

Link DOI : http://dx.doi.org/10.31314/pjia.9.2.176-185.2020

\section{INTRODUCTION}

Work effectiveness is a crucial and urgent matter for auditors. According to Tangkilisan (2005) effectiveness is a balance or optimal approach in achieving goals, abilities and utilization of human labor. So the concept of the level of effectiveness shows the extent to which the organization carries out activities or functions so that the objectives that have been set can be achieved by using tools and resources optimally. According to Siagian (2007) work effectiveness is the completion of work on time that has been determined. Work effectiveness is an effect or the desired result of a series of physical and spiritual activities carried out by humans to achieve certain goals. Effectiveness in the public sector can also be measured from the extent to which internal auditors have adequate competence, sufficient number of resources, good relationships with external auditors, the support from the auditee and the independence of the auditors themselves (Sari, Haryanto,2016).

The effectiveness of the auditor's work is seen from a condition where the auditor can work on and complete his duties based on the specified time and quantity and quality. Due to auditors' work effectiveness in auditing and supervising, this research is focused on Regional Inspectorate of Gorontalo Province as a research site. This institution is selected based on the data found in the field that there are some employees or auditors whose works have been good, yet there should be an improvement, particularly on the aspect of work effectiveness.

The work effectiveness of an auditor can be good if the fulfillment reaches $\geq$ $90 \%$ as the effective work criteria, according to Mardiasmo (2012). The 
internal auditors of Regional Inspectorate of Gorontalo Province have had effective works observed from either their quantity or quality of works. In this case, they are able to complete good quality works. However, time becomes another problem for internal auditors. They dominantly cannot achieve the target given by the leader. Also, human resources development tends to be not optimal, although it improves. Meanwhile, the Regional Government Financial Statement has achieved excellent opinion, which is Fair Predicate Without Exception (WTP). However, there is still something to be found by Audit Board of the Republic of Indonesia.It indicates that the internal auditors of Gorontalo Province need to improve their performance and work effectiveness; hence the financial statement will be excellent without any crucial thing to be concerned by BPK (Audit Board of the Republic of Indonesia). Also, IHPS BPK has found that each year, there is still a problem occurred toward the assets of Gorontalo Province that should be arranged before by the internal auditors of Gorontalo Province. Then, the problem also appears on state property. The handover of the property as the object of Capital Participation of Central Government is conducted after the determination of the government's regulation about the Capital Participation of the Central Government.

The mechanism of PMK or The Procedure for the Implementation of the Transfer of State Propertyhas been regulated, and it needs good assessment. The proper assessment will affect accounting recording. If the appraisal team, after conducting assessment on the properties, obtains inappropriate results, the accounting appreciation will also beaffected. One of the important things in creating a qualified audit is auditors' competence. According to Harhinto (2004), competence can be understood as a combination of skill, personal attribute, and knowledge reflected through job behavior that can be observed, measured, and evaluated. Setyaningrum and Kuntadi
(2019) state that competence, auditing, and communication positively influence the internal audit. It implies that auditor should be equipped with both technical and nontechnical competencies related to auditing. According to Rai (2008), auditor competence is aqualification needed by an auditor to carry out an audit properly, and in conducting an audit, an auditor must have good personal quality, adequate knowledge, and special expertise in his field. An auditor must have three competencies : 1) Knowledge, 2) Special skills and 3) Experience.

Related to competence, basically, auditors at Regional Inspectorate of Gorontalo Province have owned good knowledge and skills. However, there are some lacks particularly on the technical ability and the obedience to auditing activity that should be done properly with a plan. Besides, the competences development should be done to all employees, especially the spiritual and social competences. Hence, the auditors will be more capable of auditing independently, and they will have high integrity and ability to do their job everyday, even improve more in terms of controlling to the village government level.

Another crucial factor is the auditors' independence. According to Mulyadi (2010) Independence can mean a mental attitude that is free from influence, not controlled by other parties, does not depend on others. Independence also means the existence of honesty within the auditor in considering facts and the existence of objective, impartial considerations within the auditor in formulating and expressing his opinion. Christiawan (2003) states that independence is a good action. It is the attitude or mental of the auditors during auditing when the auditors should be able to take a position not to take a side on certain parties. According to Kovinna et al (2014), the independent attitude must include Independence in fact and independence in appearance. According to Arens, et al (2012) independence can be classified into two aspects, namely 
independent in fact and independent in appearance. Bohawia, et., al (2015) states that independence or commitment of auditors toward organization is a kind of loyalty to that organization in order to be wiser in making a decision. Independence of the auditors of Regional Inspectorate of Gorontalo Province basically has been good due to education and training. However, the mutation between divisions requires auditors to adapt to the new division. Meanwhile, from the interpersonal correlation, either kinships or other interest relations influence the independence of the apparatus. So far, research on the effectiveness of auditors' work has discussed a lot about human resources. However, this research more specifically proves the effect of competence and independence both partially and simultaneously on the effectiveness of auditors' work. The specificity is what distinguishes this study from other studies.

The problems above are the phenomena to be studied scientifically, Therefore, based on the above explanation, it is interested in conducting the research entitled "the influence of competence and independence toward work effectiveness of auditors at Regional Inspectorate of Gorontalo Province." The problem statements consist of: 1) whether or not competence influences the work effectiveness of auditors at Regional Inspectorate of Gorontalo Province; 2) whether or not independence influences the work effectiveness of auditors at Regional Inspectorate of Gorontalo Province; 3) whether or not competence and independence influence the work effectiveness of auditors at Regional Inspectorate of Gorontalo Province.

\section{RESEARCH METHODS}

The research site is Regional Inspectorate of Gorontalo Province, which is appropriate to the research's title and quite relevant to the problem statements. The research has been conducted for 4 months from November 2019 to March 2020. In order to facilitate the hypothesis test, the researcher determines the research variables. For the first variables as auditors' competence used indicators : knowledge components; psychological characteristics; decision determination strategies; thinking ability and task analysis. For the second variables auditors Independence used indicators : Independent toward personal hindrance; Independent toward external hindrance and independent toward organizational hindrance. next for third variables auditors work effectiveness used indicators : work quality; work quantity; time utilization and the improvement of human resource quality.

The research population is 75 auditors and supervisors at Inspectorate. The samples are all number or population amounted to 75 respondents. The data that have been collected are tested using Multiple regression test that the formulation as follows:

$Y=a+b_{1} X_{1}+b_{2} X_{2}+e$

Notes:

$\mathrm{Y}=$ Auditors' Work Effectiveness

$\mathrm{A}=$ Constant

$\mathrm{X}_{1}=$ Competence

$\mathrm{X}_{2}=$ Independence

$\mathrm{b}=$ Regression Coefficient

$\mathrm{e}=$ Prediction Errors

\section{RESULT AND DISCUSSION}

The use of this research approach and method is based on the certainty of the problem of the effectiveness of the work of auditors and their indicators. This problem variable can be influenced by the competency and independence variables. Based on the problem statements and research method, the findings can be explained as follows:

\section{The Appraisal of Regression Model}

After the classical assumption test is conducted, and it is attained to be fulfilled, the data modeling is conducted using multiple regression analysis which as : 
Table 1: Regression Analysis Result

\begin{tabular}{|c|c|c|c|c|c|c|}
\hline & \multirow[t]{2}{*}{ Model } & \multicolumn{2}{|c|}{$\begin{array}{c}\text { Unstandardized } \\
\text { Coefficients }\end{array}$} & \multirow{2}{*}{$\begin{array}{c}\text { Standardized } \\
\text { Coefficients }\end{array}$} & \multirow[t]{2}{*}{$\mathbf{t}$} & \multirow[t]{2}{*}{ Sig. } \\
\hline & & B & Std. Error & & & \\
\hline \multirow{3}{*}{1} & (Constant) & 4.089 & 5.204 & & .786 & .435 \\
\hline & $\begin{array}{c}\text { Independence } \\
\text { Competence }\end{array}$ & .257 & .074 & 264 & 3.464 & .001 \\
\hline & & .678 & .078 & .664 & 8.699 & .000 \\
\hline
\end{tabular}

Source: Processing data of SPSS 21, 2020

Based on the analysis result, the simple linear regression model is:

$$
\hat{Y}=4,089+0,257 X_{1}+0,678 X_{2}+e
$$

The Influence of Auditors; Competence toward Auditors; Work Effectiveness at Regional Inspectorate of Gorontalo Province

The test result of the influence of auditors' competence toward auditors' work effectiveness is presented in the following Table 2 :

Table 2: Partial Test Result of X1 toward Y

\begin{tabular}{ccc}
\hline Model & (Constant) & $\begin{array}{c}\text { Auditors' Competence } \\
\left(\mathbf{X}_{\mathbf{1}} \text { Variable }\right)\end{array}$ \\
\hline Coefficient Value (t-Count) & 0,786 & $\mathbf{3 , 4 6 4}$ \\
Significance & 0,435 & $\mathbf{0 , 0 0 1}$ \\
ttable & 1,993 \\
\multicolumn{2}{c}{ Notes } & Significantly influences \\
Significantly influences due to: \\
1. tcount value is higher than table \\
2. Significance value is lower than alpha $(0.001<0.05)$ \\
\hline
\end{tabular}

Source: Processing Data of SPSS 21, 2020

The Influence of Auditors' Independence toward Auditors' Work Effectiveness at Regional Inspectorate of Gorontalo Province

The test result of the influence of auditors' independence toward auditors' work effectiveness is presented in the following Table 3 :

Table 3: Partial Test Result of X2 toward Y

\begin{tabular}{|c|c|c|}
\hline Model & (Constant) & $\begin{array}{c}\text { Auditors' independence } \\
\left(\mathrm{X}_{2} \text { variable }\right)\end{array}$ \\
\hline Coefficient Value (t-Count) & 0,786 & 8,699 \\
\hline Significance & 0,435 & $\mathbf{0 , 0 0 0}$ \\
\hline$t_{\text {table }}$ & & 1,993 \\
\hline Notes & & Significantly influences \\
\hline $\begin{array}{l}\text { 1. tcount value is higher than } \\
\text { 2. Significance value is lov }\end{array}$ & $\begin{array}{l}\text { antly influenc } \\
\text { alpha }(0.000\end{array}$ & \\
\hline
\end{tabular}

Source: Processing Data of SPSS 21, 2020 
Available Online at http://journal.umgo.ac.id/index.php/Publik

Publik (Jurnal Ilmu Administrasi) Vol 9 (2), Desember 2020

Table 4: Simultaneous Test Result

\begin{tabular}{lllcccc}
\hline \multirow{2}{*}{ Model } & $\begin{array}{c}\text { Sum of } \\
\text { Squares }\end{array}$ & df & Mean Square & F & Sig. \\
\hline \multirow{2}{*}{1} & Regression & 7764.847 & 2 & 3882.423 & 60.559 & $.000^{\mathrm{b}}$ \\
\cline { 2 - 7 } & Residual & 4615.920 & 72 & 64.110 & & \\
\cline { 2 - 7 } & Total & 12380.766 & 74 & & & \\
\hline
\end{tabular}

Source: Processing Data of SPSS 21, 2020

Table 5: Determination Coefficient

\begin{tabular}{ccccc}
\hline Model & R & R Square & Adjusted R Square & $\begin{array}{c}\text { Std. Error of the } \\
\text { Estimate }\end{array}$ \\
\hline 1 & $.792^{\mathrm{a}}$ & .627 & .617 & 8.00687 \\
\hline
\end{tabular}

Source: Processing Data of SPSS 21, 2020

Table 6: Coefficient of Partial Determination

\begin{tabular}{cccc}
\hline \multirow{2}{*}{ Model } & Correlation & \multicolumn{2}{c}{ Determination } \\
\cline { 3 - 4 } & $(\mathbf{R})$ & $\mathbf{R}^{\mathbf{2}}$ & $\mathbf{\%}$ \\
\hline Auditors' Competence & 0.485 & 0.235 & $23,50 \%$ \\
\hline Auditors' Independence & 0.752 & 0.566 & $56,60 \%$ \\
\hline
\end{tabular}

Source: Processing Data of SPSS 21, 2020

Table 3 shows that $\mathrm{t}$-count value for auditors' competence variable is 3,464 , while t-tableat a significance level of $5 \%$ and df of $n-k-1$ or $75-2-1=72$ is 1,993 . If they are compared, $\mathrm{t}$-count will be higher than $t$-table $(3,464>1,993)$. Therefore, it can be concluded that at the confidence level of $95 \%$, auditors' competence positively and significantly influences the auditors' work effectiveness at Regional Inspectorate of Gorontalo Province. The positive coefficient indicates that the higher the competence of an auditor, the more effective the work of the auditor.

Table 3 shows that $\mathrm{t}$-count value for auditors' independence variable is 8,699, while $\mathrm{t}$-tableat a significance level of $5 \%$ and df of $n-k-1$ or $75-2-1=72$ is 1,993 . If they are compared, $t$-count will be higher than $t$-table $(8,699>1,993)$. Therefore, it can be concluded that at the confidence level of $95 \%$, auditors' independence positively and significantly influences the auditors' work effectiveness at Regional Inspectorate of Gorontalo Province. The positive coefficient indicates that the more independent an auditor in auditing and running his/her functional tasks, the more optimal the work effectiveness.
Table 4 shows that $F_{\text {count }}$ is 60,559 . At the significance level of $5 \%$ and df 1 as much as $\mathrm{k}=2$, and df 2 of $\mathrm{N}-\mathrm{k}-1=75-2-$ $1=72, F_{\text {table }}$ is 3,124 . If the two values of $F$ are compared, F-count will be much higher than Ftable. Hence, auditors' competence and independence simultaneously influence the auditors' work effectiveness at Regional Inspectorate of Gorontalo Province.

Based on the determination coefficient analysis result in Table 5, it shows that the extent of the influence (the ability of independent variables in explaining the dependent variable) using Adjusted R Square is 0,617 . It indicates that $61,70 \%$ work effectiveness variability at Regional Inspectorate of Gorontalo Province can be explained by auditors' competence and independence, while the rest $38,30 \%$ can be explained by other variables out of this research.

The concept used in this study is the measurement of the influence of competence and independence on the effectiveness of auditors' work with measurable indicators. The goal is to test and prove the predetermined hypotheses. 
Based on the findings, the explanation can be as follows:

\section{The Influence of Auditors' Competence toward Auditors' Work Effectiveness at Regional Inspectorate of Gorontalo Province}

Competence is an ability, skill (education and training), and experience in understanding the criteria in determining the evidence needed to support the conclusion to make. The descriptive analysis result, which is the comparison between actual score with an ideal score, finds that the auditors' competence variable lies in "competent" criteria with a score of $79,90 \% .24$ respondents or for $32,00 \%$ are categorized to very competent criteria, 47 respondents or $62,70 \%$ are categorized to competent criteria, and 4 respondents or $5,30 \%$ are categorized to sufficient criteria.

It shows that the auditors at Regional Inspectorate of Gorontalo Province have good knowledge in terms of knowledge and skill that can be used to maximize their work in relation to auditing and administrative procedures and financial management at Gorontalo Province Government. The competent auditors will be able to do a job based on the quality, quantity, time utilization target in performing audit and functional control toward the institutions in Gorontalo Province. Due to the competence, the decision making for a recommendation of audit results will be based on the actual fact in the field. It is supported by Hasibuan in Sulila (2019) that competence is the basic characteristic related to an individual's work effectiveness in working, showing that if an auditor has adequate competence, his/her work will fulfill the target.

The first hypothesis verification through multiple regression tests shows that auditors' competence positively and significantly influences the auditors' work effectiveness at Regional Inspectorate of Gorontalo Province with determinant value for $23,50 \%$. The indication of the positive coefficient is that the higher the auditors' competence, the more effective the work achievement of the auditors at Regional Inspectorate of Gorontalo Province. Besides, a cell in cross tabulation is dominated by auditors who are incompetent criteria and have effective work amounted to 38. It shows good influence of the auditors' competence in making the auditors have optimal work achievement.

The auditors' competence, although the result has been significant through Tuckey test (t-test), observing the determination value, it should be improved. It is because the auditors' competence in this research is measured from the visible aspect (intellectual intelligence), while invisible aspects, namely emotional and spiritual intelligence, are difficult to measure, hence the result is not really affecting the work effectiveness. It is based on the statement that competence includes two levels: visible and invisible. If all aspects of competence are optimized, it will affect the qualified and effective work achievement.

This result is along with the statement of Kharismatuti and Hadiprajitno (2012:33) that competence as the adequate skill explicitly can be used to do audit objectively.

The influence of auditors' independence toward auditors' work effectiveness at Regional Inspectorate of Gorontalo Province

The descriptive analysis result, which is the comparison between actual score and ideal score, shows that auditors' 
independence variable lies in "independent" criteria with a score of $80,27 \%$. 23 respondents or $30,70 \%$ are in very independent criteria, 49 respondents or $65,30 \%$ are in independent criteria, and 3 auditors or $4,00 \%$ are in sufficient criteria in carrying their responsibility. It indicates that auditors at Regional Inspectorate of Gorontalo Province have a good independent attitude or unshakeable in doing their tasks and responsibilities as internal auditors at Gorontalo Province Government. This independent attitude is showed by the auditors clearly toward findings that need to be improved by the institutions (Regional Work Unit) related to the internal controlling system, financial management, and public service administration and technic. This attitude is continuously kept by auditors in order to be able to work based on the ethical code. Thus, the audit result will be truly effective as the measurement of the work achievement of the auditors of Regional Inspectorate of Gorontalo Province.

Factor influencing the audit quality is the auditors' obedience toward the ethical code reflected from the independence attitude, objectivity, and integrity. It shows that the attitude of the government officers will determine the effectiveness of carrying out their tasks and responsibilities. It is supported by Sulila (2019) that the attitude of the implementer becomes a crucial aspect in influencing a program and its implementation in which one of the programs is doing an audit or administrative and financial management in Gorontalo Province Government. Implementers' independent attitude makes the audit result is qualified, which indicates the good work of the auditors or the effective process and the auditors' work achievement is based on the plan.
The second hypothesis test through multiple regression test shows that auditors' independence positively and significantly influences the auditors' work effectiveness at Regional Inspectorate of Gorontalo Province by having determination value for $56,60 \%$. A positive coefficient indicates that the higher the auditors' independence in doing audit and running their functional controlling function, the more optimal the effectiveness of the work of the auditors at Regional Inspectorate of Gorontalo Province. Besides, a cell in cross tabulation is dominated by auditors who are independent in carrying their responsibility and are able to achieve the effective work amounted to 39. It shows that independence is able to make a good contribution in striving for the more effective work achievement of the auditor at Regional Inspectorate of Gorontalo Province. Overall, this finding is appropriate to the statement of Winda and Sofie (2014) that independence is an attitude of auditors to not taking a side, not having personal interest, and being difficult to be influenced by certain parties to give an opinion.

\section{The influence of auditors' competence} and auditors' independence simultaneously toward auditors' work effectiveness at Regional Inspectorate of Gorontalo

The descriptive analysis result, which is the comparison between actual score and ideal score, shows that auditors' work effectiveness variable lies in very effective criteria with a score of $79,48 \%$. 17 respondents or $22,70 \%$ are categorized very effective in working, 56 respondents or $74,70 \%$ are in effective category, and 2 respondents or $2,70 \%$ are in sufficient 


\section{Available Online at http://journal.umgo.ac.id/index.php/Publik \\ Publik (Jurnal Ilmu Administrasi) Vol 9 (2), Desember 2020}

Jurnal IImu Administrasi

category in running their task as an internal auditor at Gorontalo Province government.

It shows that auditors at Regional Inspectorate of Gorontalo Province are able to achieve the actual works based on the target or work plan. The tendency of the appropriate work target achievement affects the work result and the achievement of visions and missions. Auditors who are able to work effectively indicate that the auditors have optimized their inner aspects related to independent attitude so that they are able to work professionally as internal auditors in creating good government management.

The work effectiveness of the auditors is to improve the financial management of the local government. The essential of local financial management should always be controlled and checked as according to Sulila (2019) that financial management is an effort to find out the local financial resource by looking for the local structured potential and ability. The internal auditor should assess the work, operation, or program to see whether or not the result has been appropriate to the goals and targets that have been determined before. The adjustment between planning and result can be achieved by the optimality of auditors' competence and independent attitude.

The third hypothesis test result through multiple regression test shows that auditors' competence and auditor's independence simultaneously have significant influence toward auditors' work effectiveness at Regional Inspectorate of Gorontalo Province with the determinant value for $61,70 \%$, while the rest $38,30 \%$ can be explained by other variables such as auditors' education, integrity, motivation, work discipline, and professionality attitude. If the auditor's competence is followed by an independent attitude then the auditors' work effectiveness at
Regional Inspectorate of Gorontalo Province will be appropriate to the expectation of either the auditors themselves or the head of the institution. This result is in line with Elfarini (2007) and Justinia (2008), who states that competence and independence simultaneously influence the audit quality.

\section{CLOSING}

\section{Conclusion}

Based on the findings and discussion, it can be concluded that : 1) Auditors' competence positively and significantly influences the auditors' work effectiveness at Regional Inspectorate of Gorontalo Province with determinant value for $23,50 \%$. It indicates that the higher the auditors' competence, the more effective the work achievement of the auditors at Regional Inspectorate of Gorontalo Province. 2) Auditors' independence positively and significantly influences the auditors' work effectiveness at Regional Inspectorate of Gorontalo Province by having determination value for $56,60 \%$. The indication of the positive coefficient is that the higher the auditors' independence in doing audit and running their functional controlling function, the more optimal the effectiveness of the work of the auditors at Regional Inspectorate of Gorontalo Province. 3) Auditors' competence and auditor's independence simultaneously have significant influence toward auditors' work effectiveness at Regional Inspectorate of Gorontalo Province with the determinant value for $61,70 \%$, while the rest $38,30 \%$ can be explained by other variables such as auditors' education, integrity, motivation, work discipline, and professionality attitude.

\section{Suggestion:}

It is suggested that : 1) The Regional Inspectorate of Gorontalo Province should be active in following the training that can Copyright $@$ 2020, Publik (Jurnal Ilmu Administrasi), ISSN: 2301-573X (Print), ISSN: 2581-2084 (Online) 
improve knowledge in auditing. The training should be followed seriously so that the result will be more meaningful for the development of the knowledge and competence of the internal auditors. 2) The internal auditors in Gorontalo Province should keep the attitude by having high commitment proved by their ability to reveal findings although they are done by their colleagues. 3) The internal auditors should always give and do an examination as well as possible. Then, the leader should allocate his/her time to check the work of the auditors and to pay attention to the task accomplishment trend in the previous period. The leader should ask other auditors who have completed their task to be willing to help those who have not yet completed their task, but not on technical things in the field.

\section{REFERENCES}

Arens, Alvin A, Randal J. Elder dan Beasley Mark S, (2012). Auditing and Assurances Services - An Integrated Approach, Edisi Kedua belas, Prentice Hall

Bohawia, Mohammed.S; Gugus Irianto and Zaki Baridwan. (2015). The Effect of Working Experience, Integrity, Competence, and Organizational Commitment on Audit Quality (Survey State Owned Companies In Libya), IOSR Journal of Economics and Finance (IOSR-JEF) e-ISSN: 2321-5933, p-ISSN: 23215925.Volume 6, Issue 4. Ver. II (Jul. - Aug. 2015), PP 60-67 www.iosrjournals.org

Christiawan, Yulius Jogi, (2003), Kompetensi dan independensi akuntan publik : refleksi hasil penelitian empiris. Jurnal Akuntansi dan Keuangan, Vol.4, (No.2)
Dahlia Lia, Ellyn Octavianty. (2016). Pengaruh Kompetensi, Independensi dan Profesional Auditor terhadap Kualitas Audit. JIAFE (Jurnal Ilmiah Akuntansi Fakultas Ekonomi) Volume 2 No. 1, Edisi 2, Hal. 16-37

Elfarini, E.C. (2007). Pengaruh Kompetensi dan Independensi Auditor terhadap Kualitas Audit. Universitas Negeri Semarang

Harhinto, Teguh. (2004). Pengaruh Keahlian dan Independensi Terhadap Kualitas Audit Studi Empiris Pada KAP di Jawa Timur, Semarang, Tesis Maksi Universitas Diponegoro

Hadiprajitno. (2012). Kharismatuti, Norma dan P. Basuki. "Pengaruh Kompetensi dan Independensi terhadap Kualitas Audit dengan Etika Auditor sebagai Variabel Moderasi” (Studi Empiris pada Internal Auditor BPKP DKI Jakarta), Diponegoro Journal of Accounting Vol.1 No.1 Hal 1-10

Justinia, Castellani. (2008). Kompetensi dan Independensi Auditor Pengaruhnya pada Kualitas Audit. Jurnal Trikonomika, Vol 7, No. 2, Desember. 114:121

Kovinna, Fransiska dan Betri, (2014). Pengaruh Independensi, Pengalaman Kerja, Kompetensi Dan Etika Auditor Terhadap Kualitas Audit (Studi Kasus Pada Kantor Akuntan Publik Di Kota Palembang), Skripsi, STIE MDP, Palembang

Mardiasmo, (2012). Akuntansi Sektor Publik, Yogyakarta: Penerbit Andi

Mulyadi. (2010). Auditing, Edisi Keenam, Buku 1. Jakarta: Penerbit Salemba Empat

Rai, I Gusti Agung. (2008). Audit Kinerja pada Sektor Publik. Jakarta: Penerbit Salemba Empat. 
Sari Dea Nurfika, Haryanto. (2016). Analisis Determinan Efektifitas Auditor Internal Pada Inspektorat Provinsi Daerah Istimewa Yogyakarta. Jurnal Akuntansi \& Auditing, Volume 13/No. 2

Setyaningrum Kuntadi, Dyah. (2019). Pengaruh Kompetensi,Independesni, Pekerjaan Audit dan Komunikasi terhadap Efektivitas Audit Internal, Cris Journal of Economics, Business \& Accountancy Ventura Vol 22, No 1 (2019)

Siagian, Sondang, P. (2007). Teori Pengembangan Organisasi. Jakarta: Bina Aksara

Sulila, Ismet, (2019) Regional Financial Public Services Evaluation Based on Regional Budget and Expenditure. Jurnal Sosial dan Pembangunan MIMBAR. Volume 35 Nomor 2. Page 295-305 Print ISSN: 02158175; Online ISSN: 2303-2499. DOI:

https://doi.org/10.29313/mimbar.v35i 2.4674

Sulila, Ismet. (2019). An Analysis of the Effectiveness of Allocation of Village Fund Policy Implementation and Its Determining Factors in Gorontalo Regency. Jurnal Ilmiah Ilmu Administrasi Publik: Jurnal Pemikiran dan Penelitian Administrasi Publik Volume 9 Number 2, July- December 2019. Page 67-78 p-ISSN: 2086-6364, eISSN: 2549-7499. DOI: https://doi.org/10.26858/jiap.v9i2.10 $\underline{947}$

Sulila, Ismet. (2019). The Effect of Human Resource Competency and Implementation of SIMDA on the Quality of Financial Statement at BPKAD Office of Gorontalo City. Jurnal PUBLIK (Jurnal Ilmu Administrasi). Universitas
Muhammadiyah Gorontalo, Volume 8 Nomor 1. Page 67-74. ISSN: 2301573X (Print), ISSN: 2581-2084 (Online).

DOI: http://dx.doi.org/10.31314/pjia.8.1.67 $\underline{-74.2019}$

Tangkilisan, Hessel Nogi S. (2005). Manajemen Publik, Jakarta: Grasindo

Winda, Khomsiyah dan Sofie. (2014). Pengaruh Kompetensi, Independensi, Tekanan Waktu, dan Etika Auditor Terhadap Kualitas Audit. E-Jurnal Akuntansi Fakultas Ekonomi. Universitas Trisakti, Volume 1 Nomor 2 September 2014, Hal 49-67, ISSN:2339-0832. 